IJOTL TL, Vol. 4, No. 3, September 2019

p ISSN: 2502 2326; e ISSN: 2502 8278

Https://soloclcs.org; Email: ijolt1@gmail.com

Center of Language and Cultural Studies, Surakarta, Indonesia

Nugroho, Prasetio Anggit. 2019. Communication Strategies Used by EFL Learners with Different English Achievements in Oral Communication.

IJOTL TL (2019), 4(3): 138 155. DOI: 10.30957/ijotl-tl.v4i3.606.

\title{
Communication Strategies Used by EFL Learners with Different English Achievements in Oral Communication
}

\author{
Anggit Prasetio Nugroho \\ IAIN Pattahul Muluk, Jayapura Papua-Indonesia \\ anggitprasetio72@gmail.com
}

\begin{abstract}
This article aims to identify the communication strategies used by the learners with low and high English achievement in classroom oral communication and to describe the difference of the frequency of using communication strategies from low and high achievement learners. This research used a descriptive research. The researcher used a case-study design because the present research concentrated on communication strategies used by the learners with low and high English achievement in a specific setting. The 30 learners of the eleventh-grade learners at SMA Negeri 1 Malang was selected as research subject. The result showed that the learners employed 14 communication strategies. The mostly used by the learners was time-gaining strategy and followed by self-repetition, self-repair, appeal for help, code-switching, circumlocution, approximation, use of all-purpose word, other-repetition, message abandonment, other correction, topic avoidance, use of non-linguistic mean, and literal translation. This research also found that the learners with low English achievement used communication strategies more frequently than the learners with high achievement.
\end{abstract}

Keywords: communication strategies, achievement, oral communication

\section{INTRODUCTION}

In English language learning, teaching speaking aims to enable the learners to use the language for communication. According to Harmer (2012:116), there are a variety of classroom activities which provide the learners to retrieve and use the target language, such as interview, discussion, telling stories, and role-play. The teachers need to provide the learning through these activities in order to encourage the learners to be able to communicate using the target language. Therefore, the teachers should encourage the learners to use the target language for communication in the classroom.

However, the language learners need to have a complete understanding of communicative competence in order to be able to communicate effectively. According to Cravotta (2007), if the learners want to communicate effectively, they need to have an adequate understanding of communicative competencies. There are four communicative competencies that should be learned by the language learners, namely grammatical competence, discourse competence, sociolinguistic competence, and strategic competence (Brown, 2000:247). The learners need to know how to convey the ideas comprehensively and recognize the way how to overcome their problems in communication. Therefore, by knowing and learning these communicative 
IJOTL TL, Vol. 4, No. 3, September 2019

p ISSN: 2502 2326; e -ISSN: 2502 8278

Https://soloclcs.org; Email: ijolt1@gmail.com Center of Language and Cultural Studies, Surakarta, Indonesia

Nugroho, Prasetio Anggit. 2019. Communication Strategies Used by EFL Learners with Different English Achievements in Oral Communication.

IJOTL TL (2019), 4(3): 138 155. DOI: 10.30957/ijotl-tl.v4i3.606.

competencies, it can lead the learners to communicate comprehensively. In sum, the language learners need to struggle in order to be able to communicate effectively.

The foreign language learners face some problems in developing their speaking ability. Sometimes, they cannot express their ideas in English with other people fluently because of their inadequate competence in the target language. In other words, there are linguistic and non-linguistic aspects in speaking problems that are experienced by the learners (Al Hosni, 2014). For example, the learners have difficulties in speaking English because they have deficiencies in the target language knowledge, such as grammar, pronunciation, vocabulary, fluency, and comprehension. In addition, lack of self-confidence, anxiety, motivation, and few opportunities to practice the language are identified as the non-linguistic factors that cause the speaking problems (Alrabai, 2014). It is supported by Ahmed et al. (2017) who declare that speaking class is seen as the place where the anxiety potentially appears in the language learners' learning process. In other words, the language learners encounter some communication problems when they communicate using the target language.

In this issue, strategic competence can assist the language learners to overcome the communication problems. Strategic competence is the speaker's technique to overcome the communication problems which covers the knowledge of verbal and nonverbal communication strategies that are recalled by the speakers to compensate communication breakdowns because of their target language deficiency. It is supported by Canale and Swain (2000:248) who stated that communication strategies help the learners to overcome some communication problems. Thus, communication strategies support the flow of the learners' communication when they have inadequate of the target language resources.

In performing oral communication, the eleventh-grade learners of SMA Negeri 1 Malang still face communication problems. It can be seen from the result of the preliminary study that the learners employed some of communication strategies. They apply some of compensatory strategies, such as code-switching, appeal for help, and time-gaining strategies. Although the learners encounter some problems in their communication, they still struggle to maintain their interaction with the interlocutors (Malasit\&Sarobol, 2013). Therefore, an intensive observation is needed to scientifically investigate more about the communication strategies employed by the learners in performing oral communication.

The learners use communication strategies in their communication when they encounter difficulties in expressing their ideas. This is supported by Sari (2014) and Nurdini (2017) that the learners use communication strategies with the aims to be able to communicate well. It can be noticed that communication strategies can help the learners' conversation keep running in spite of limited knowledge of the target language. So, the communication strategy is a mean to help the language learners encounter communication problems in oral communication.

Communication strategies play a significant role in the teaching and learning English as a foreign language, particularly in speaking skill. Communication strategies can assist the learners to overcome their communication problems or reduce the communication breakdowns. It is in line with Al Alawi (2016) who revealed that 
IJOTL TL, Vol. 4, No. 3, September 2019

p ISSN: 2502 2326; e ISSN: 2502 8278

Https://soloclcs.org; Email: ijolt1@gmail.com

Center of Language and Cultural Studies, Surakarta, Indonesia

Nugroho, Prasetio Anggit. 2019. Communication Strategies Used by EFL Learners with Different English Achievements in Oral Communication.

IJOTL TL (2019), 4(3): 138 155. DOI: 10.30957/ijotl-tl.v4i3.606.

communication strategies can assist the language learners in exchanging their ideas using the target language orally. Therefore, language learners can utilize communication strategies to compensate for their target language deficiencies in communication. This is closely related toWicaksono's (2014) statement that the learners employ some communication strategies in order to communicate effectively. In other words, communication strategies are helpful for language learners in developing their speaking skills.

Furthermore, the learners' proficiency levels have an influence on the use of communication strategies in language learning. According to Poulisse(1993: 183), the use of communication strategies by the learners is proficiency-related. It means that the use of communication strategies by the learners is influenced by their proficiency level. For instance, less proficient learners use more communication strategies more frequently than high proficient learners. It is supported by numerous scholars who confirmed that the levels of learners' proficiency affected the learners' use of communication strategies (Al Alawi, 2016; and Ounis, 2016).

In short, this research is aimed to give a clear example of what communication strategies employed by the learners with the different English achievements in their classroom oral communication. Furthermore, this research is also aimed to give a clear understanding of how the frequency of using communication strategies differs from low and high achievement learners.

The problem of this research is focused on exploring the communication strategies used by learners who have high and low English achievement. In addition, this research is limited to the eleventh-grade learners of senior high school at SMA Negeri 1 Malang. This research concentrates on the learners' performance in exchanging their ideas orally in the classroom through some classroom activities, such as presentation, discussion, and asking and answers the questions.

In order to make the discussion more accurate and appropriate, the researcher formulated the following research questions:

1) What communication strategies are employed by learners with high and low English achievement in the classroom oral communication?

2) How does the frequency of using communication strategies differ from low and high achievement learners?

\section{LITERATURE REVIEW}

\subsection{Communication Strategies}

Experts define communication strategies from different approaches. Ellis (2008:502) added that communication strategies can be defined from two different points of views. Ellis proposed interactional and psycholinguistic definitions to define communication strategies based on two experts. Tarone (1980) studied the communication strategies from the interactional perspective. On one hand,Færch and Kasper (1980) perceived the communication strategies from the psychological approach. In other words, communication strategy is can be defined from two broad theoretical approaches. 
IJOTL TL, Vol. 4, No. 3, September 2019

p ISSN: 2502 2326; e ISSN: 2502 8278

Https://soloclcs.org; Email: ijolt1@gmail.com Center of Language and Cultural Studies, Surakarta, Indonesia

Nugroho, Prasetio Anggit. 2019. Communication Strategies Used by EFL Learners with Different English Achievements in Oral Communication.

IJOTL TL (2019), 4(3): 138 155. DOI: 10.30957/ijotl-tl.v4i3.606.

Tarone (1980:420) defines communication strategy is mutual attempts of two interlocutors to agree on a meaning in a situation where the intended meanings do not seem to be shared. Communication strategies are seen as a tool to be used in a negotiation of meaning where both interlocutors are struggling to agree as to communicative goal. According to Tarone (1980), communication strategies are considered as conscious strategies used by the speaker to overcome the problems in communication. Some communication problems are influenced by the speakers' deficiency in L2 knowledge. In a communication, both of the speaker and interlocutor are responsible for the success of the communication itself. When the speakers and interlocutors are aware if they do not understand each other, they will utilize a number of communication strategies.

On the other hand, Færch and Kasper (1980: 60) define communication strategies from the psychological perspective. They describe communication strategies as the speaker's conscious plans for solving their problem in exchanging the ideas. In the Færch and Kasper model, communication strategies are seen as strategic plans. The language learners use communication strategies because of they have deficiency in the target language resources or they cannot recall resources. Færch and Kasper claim that communication strategies are employed by the learners consciously, but some others are not conscious. In other words, communication strategies refer to the strategies used by the learners to reach the goal of communication when they meet some communication problems.

Based on the descriptions above, the researcher can conclude that communication strategies are the speaker's effort to make the communication keeps going on when the speaker has problems in the target language resource. The main purpose of communication strategies is to deal with the communication problems. The learners often face some difficulties in expressing their intended ideas because they have limited knowledge of the target language. Hence, communication strategies are the tools which can be used when the learners face problems in communication.

\subsection{Typology of Communication Strategies}

There are several typologies of communication strategies. The researcher displays three typologies of communication strategies which are recognizable among the researchers. They are conscious strategy, problem-oriented strategy, and productoriented strategy. The description of the typologies is presented in the following subtopic.

\subsubsection{Conscious Strategies}

Tarone (1977) issues the typology of communication strategies based on the interactional perspective. The Tarone's taxonomy of communication strategies is described as a consciousness because it perceived as the effort which is made by the speakers and the interlocutors to agree on a meaning when there is a problem in their communication. Tarone also explains that communication strategies are used by the speakers to overcome the problems in communication consciously because of their deficiency in the target language. Since these strategies reflect the learners' attempts to 
IJOTL TL, Vol. 4, No. 3, September 2019

p ISSN: 2502 2326; e ISSN: 2502 8278

Https://soloclcs.org; Email: ijolt1@gmail.com

Center of Language and Cultural Studies, Surakarta, Indonesia

Nugroho, Prasetio Anggit. 2019. Communication Strategies Used by EFL Learners with Different English Achievements in Oral Communication.

IJOTL TL (2019), 4(3): 138 155. DOI: 10.30957/ijotl-tl.v4i3.606.

make themselves understand their interlocutors' meaning, they are considered as an interactional in nature. Further, Tarone (1977:197) categorizes the communication strategies into avoidance, paraphrase, conscious transfer, appeal for help, and mime. The strategies are explained below.

\section{Avoidance}

$\boldsymbol{a}$. Topic avoidance: avoiding reference to a salient object for which learner does not have necessary vocabulary.

$\boldsymbol{b}$. Message abandonment: the learner begins to refer to an object but gives up because it is too difficult.

\section{Paraphrase}

a. Approximation: the learner uses an item known to be incorrect but which shares some semantic features in common with the correct item (e.g.' worm' for 'silkworm').

b. Word coinage: the learner makes up a new word (e.g. "person worm" to describe a picture of an animated caterpillar).

c. Circumlocution: the learner describes the characteristics of the object instead of using the appropriate TL item(s).

\section{Conscious transfer}

a. Literal translation: the learner translates the word for word from the native language (e.g. "He invites him to drink" in place of "They toast one another").

b. Language switch: the learner inserts words from another language (e.g. 'balon' for 'balloon'

c. Appeal for assistance: the learner consults some authority - a native speaker, a dictionary.

d. Mime: the learner uses a non-verbal device to refer to an object or event (e.g. clapping hands to indicate 'applause').

\subsubsection{Problem-oriented Strategies}

Dornyei (1995) classifies the types of communication strategies based on the problem-oriented perspective. In the Dornyei's typology, the types of communication strategies are distinguished from how the speakers involved in handling the problems in communication. In this taxonomy, the communication strategies refer to the speakers' strategy which is used when they encounter some problems in their communication. Similar to the previously, the communication problems are caused by the deficiency of the target language. Then, Dornyei (1995:58) classifies communication strategies into three strategies. They are avoidance strategies, compensatory strategies, and timegaining strategy. 
IJOTL TL, Vol. 4, No. 3, September 2019

p ISSN: 2502 2326; e ISSN: 2502 8278

Https://soloclcs.org; Email: ijolt1@gmail.com

Center of Language and Cultural Studies, Surakarta, Indonesia

Nugroho, Prasetio Anggit. 2019. Communication Strategies Used by EFL Learners with Different English Achievements in Oral Communication.

IJOTL TL (2019), 4(3): 138 155. DOI: 10.30957/ijotl-tl.v4i3.606.

Avoidance strategy involves an alteration, a reduction, or a complete abandonment of an intended message. Compensatory strategy offers some alternative plans for the speakers to carry out their intended meaning by manipulating the language. Whereas time-gaining strategy is not used to compensate any linguistic deficiencies, but to gain more time to keep the communication still open when the speakers face difficulties. Altogether there are twelve strategies in this typology of communication strategies. The classification of the communication strategies in this typology is explained below.

\section{Avoidance or Reduction Strategies}

a. Message abandonment: leaving a message unfinished because of language difficulties.

b. Topic avoidance: avoiding topic areas or concepts which pose language difficulties.

\section{Achievement or Compensatory Strategies}

a. Circumlocution: describing or exemplifying the target object or action

b. Approximation: using an alternative term which expresses the meaning of the target lexical item as closely as possible.

c. Use of all-purpose words: extending a general, empty lexical item to contexts where specific words are lacking.

d. Word-coinage: creating a non-existing L2 word based on a supposed rule.

e. Use of non-linguistic means: mime, gesture, facial expression, or sound imitation.

f. Literal translation: translating literally a lexical item, an idiom, a compound word or structure from L1 to L2.

g. Foreignizing: using a L1 word by adjusting it to L2 phonologically (i.e., with a L2 pronunciation) and/or morphologically.

h. Code-switching: using a L1 word with L1 pronunciation or a L3 word with L3 pronunciation in L2.

i. Appeal for help: turning to the conversation partner for help either directly or indirectly.

\section{Stalling or Time-gaining Strategies}

a. Use of fillers/hesitation devices: using filling words or gambits to fill pauses and to gain time to think.

From this taxonomy of communication strategies, it gives the researcher a framework how to formulate the research instrument in order to collect the data. The researcher develops an observation checklist based on this theory. There are twelve types of communication strategies stated in the observation checklist that is used to collect the data from the participants. Therefore, the expected data of this research includes the twelve types of communication strategies as proposed by Dornyei above.

\section{Product-oriented Strategies}

Additionally, some researchers at Nijmegen University (1977 in Ellis, 2008:507) criticized the existing typologies of communication strategies as mainly productoriented. Ellis (2008:507) explains that the Nijmegen researchers found two major 
IJOTL TL, Vol. 4, No. 3, September 2019

p ISSN: 2502 2326; e ISSN: 2502 8278

Https://soloclcs.org; Email: ijolt1@gmail.com

Center of Language and Cultural Studies, Surakarta, Indonesia

Nugroho, Prasetio Anggit. 2019. Communication Strategies Used by EFL Learners with Different English Achievements in Oral Communication.

IJOTL TL (2019), 4(3): 138 155. DOI: 10.30957/ijotl-tl.v4i3.606.

deficits in the existing taxonomy of communication strategies. They find that the first deficit is a failure to distinguish the psychological process from the linguistic product and the second is a failure to consider the linguistic and non-linguistic constraints that influence the choice of communication strategies. Therefore, they develop a taxonomy based on two characteristics, namely conceptual strategy and linguistic strategy. Conceptual strategy manipulates the target concept of the language in order to make it understandable by the interlocutors through available linguistic resources. This strategy covers analytic strategy and holistic strategy. Linguistic strategy covers morphological creativity and transfer. The description of each strategy is explained below.

\section{Conceptual Strategies}

- Analytic strategies: specifying characteristic features of the concept (e.g., circumlocution, description, and paraphrase).

- Holistic strategies: using a different concept which shares characteristics with the target item (e.g., approximation).

\section{Linguistic or code strategies}

- Morphological creativity: creating a new word by applying L2 morphological rules to a L.2 word (e.g., grammatical word coinage).

- Transfer: transferring from another language (e.g. borrowing, foreignizing, and literal translation).

Based on the typologies of communication strategies presented above it is obvious that there is a similarity among Dornyei's ,Tarone's, and Nijmegen's taxonomies of communication strategies. They present seven types in common, which includes message abandonment, topic avoidance, circumlocution, approximation, word coinage, literal translation, and appealing for help. On the other hand, Dornyei presents more types of communication strategies from Tarone and Nijmegen. Compared to Tarone, Dornyei presents three more types, which are use of all-purpose word, foreignizing, and time-gaining strategies. In addition, Nijmegen presents fewer strategies than Dornyei and Tarone. Nijmegen omits topic avoidance and message abandonment strategies. Therefore, Dornyei's taxonomy proposed more strategies and more details that encourage researchers to use them in the investigation.

For the purpose of this research, the researcher decides to employ the taxonomy of communication strategies proposed by Dornyei (1995). Dornyei suggested that a problem-oriented has become the primary defining criterion for communication strategies. It is in line with Avval (2012) who confirmed that Dornyei's classification of communication strategies is based on the consequence of the communication, either success or abandoned. The rationale for using this taxonomy is that it is built on interrelated strategies in problem resolution and achieving communication goals as the learners use the strategies when they seem to have difficulty in communicating. It is supported by Rustantya (2016) that Dornyei's taxonomy is more appropriate for Indonesian learners who learn English as a foreign language. Moreover, Dornyei's typology gives more complete types of communication strategies which can represent 
IJOTL TL, Vol. 4, No. 3, September 2019

p ISSN: 2502 2326; e ISSN: 2502 8278

Https://soloclcs.org; Email: ijolt1@gmail.com

Center of Language and Cultural Studies, Surakarta, Indonesia

Nugroho, Prasetio Anggit. 2019. Communication Strategies Used by EFL Learners with

Different English Achievements in Oral Communication.

IJOTL TL (2019), 4(3): 138 155. DOI: 10.30957/ijotl-tl.v4i3.606.

the communication strategies that might be employed by the learners (Grzegorzewska, 2015).

There are totally twelve communication strategies suggested by Dornyei (1995) that will be observed in this research. They are message abandonment, topic avoidance, circumlocution, approximation, use of all-purpose word, word coinage, use of nonlinguistic signal, literal translation foreignizing, code-switching, appeal for help, and time gaining strategy.

\section{METHODS}

This research used a descriptive method.This research employed a case study design since the result of the preliminary study showed that even though all the learners from the other classes actively involved in the classroom communication, the learners from this selected class showed that they were more active using communication strategies when expressing their ideas.This research would represent the learners' use of communication strategies and described the different frequency of using the strategies between the students with low and high achievement based on the tabulation of frequency.

The source of data was the eleventh-grade learners of SMA Negeri 1 Malang. The instruments used in this research were observation sheet, interview, documentation, and field note. The data of this research were the various communication strategies used by the learners. The learner's communication strategies were gained from the learners' communication that happened in the classroom. Besides, the learners' behaviours when they are communicating in the classroom including their gesture, facial expression, and eye contact were considered also as the data of this research because they were included as non-verbal strategies.

\section{FINDINGS AND DISCUSSION}

This section attempts to answer the problems raised in this research which covers the use of communication strategies used by the learners and the different of frequency of using communication strategies from low and high achievement learners.

\subsection{Communication Strategies Used by the Learners}

It was found that the learners used 14 types of communication strategies in their classroom oral communication. In detail, the learners implemented 10 strategies of Dörnyei's (1995) taxonomy and they also employed four other strategies out of the strategies proposed by Dörnyei's (1995). Each strategies are described below.

Topic avoidanceis identified as the speakersimply does not talk about the concept for which the target language item is not known. This strategy was employed only twice by two different learners. The example of this strategy was presented in corpus TA/S15/D3, "I don't know ..." The Student 15 rejected to talk about the description about her superpower when she performed an interactive presentation with his group. She used the strategy in this following situation:

Student 9 : Can you describe your superpower? 
IJOTL TL, Vol. 4, No. 3, September 2019

p ISSN: 2502 2326; e ISSN: 2502 8278

Https://soloclcs.org; Email: ijolt1@gmail.com

Center of Language and Cultural Studies, Surakarta, Indonesia

Nugroho, Prasetio Anggit. 2019. Communication Strategies Used by EFL Learners with

Different English Achievements in Oral Communication.

IJOTL TL (2019), 4(3): 138 155. DOI: 10.30957/ijotl-tl.v4i3.606.

Student 15 : Em.. it is like(laughing) I don't know, Pak.

From the data above, it showed that the learner stopped talking because she lacked knowledge about the topic that she chose to describe. Therefore, the speaker said that she did not know and then quiet.

\section{Message abandonment}

Corpus MA/S2/D5 was the example of this strategy, "The story is about a family who lives so far away, but they are still ..." From the corpus, the Student 2 abandoned his message because he did not know how to express his idea in the target language. The student admitted that he would explain that the characters in that story still had a sensitive feeling with each other, but he did not know how to express it in English at that particular time.

\section{Circumlocution}

The use of this strategy was proven by the result of the following interview.

Do you use circumlocution strategy in speaking English? Why? And why not?

Yes, because, for example, if I forget the vocabulary or I do not know in English. For me, it is easier to use this. For example, a cutter is something that we use to cut something like paper. (Student 2);

From the data above, the learner revealed that he employed circumlocution strategy in his speaking. It was an effort to overcome the communication problem when the learner did not know or forget the intended meaning in the target language.

\section{Approximation}

In this research, even though the alternative items that the learners used sounded inappropriate, they seemed to successfully help the audiences to catch the general meaning of what the speaker wanted to say. An utterance, "In the bird island, there is a man bird named Mad, ..." which was coded App/S12/D5 was the example of the use of approximation strategy. It revealed that the term man bird was selected by the Student 12 to replace the term male when this term did not exist in her mind at that particular moment.

\section{Use of all-purpose word}

The use of this strategy was proven by the result of the following interview.

Do you use of all-purpose words strategy in speaking English? Why? And why not?

Yes, I do, because I do not know what I want to say next. I use it, for example, when giving an example about something but I do not know how to say it in English, so that I just said, "like that". (Student 6);

Yes, I do, because sometimes I do not realize it, but I usually use these words to mean just like that. For example, I said, "something like that" is to replace what all I mean at that time. (Student 4); 
IJOTL TL, Vol. 4, No. 3, September 2019

p ISSN: 2502 2326; e ISSN: 2502 8278

Https://soloclcs.org; Email: ijolt1@gmail.com

Center of Language and Cultural Studies, Surakarta, Indonesia

Nugroho, Prasetio Anggit. 2019. Communication Strategies Used by EFL Learners with Different English Achievements in Oral Communication.

IJOTL TL (2019), 4(3): 138 155. DOI: 10.30957/ijotl-tl.v4i3.606.

From the data above, the learners revealed that they used certain words repeatedly in their oral communication to replace the intended terms that they forgot or did not know how to express them in the target language

\section{Non-linguistic signals}

The implementation of this strategy could be seen from the corpus UNM/S5/D2, "He would be a Spiderman, so he would (moving her hand to imitate a jumping movement) from one city to another". This corpus can be understood through the elaboration of this following excerpt:

Teacher : Alright, please tell us what superpower your friend wants to have?

Student 5 : My friend, Rafli, would be a Spiderman, so he would (movingher hand to imitate a jumping movement) from one city to another.

From the data above, the speaker tried to use her body language to express her intended message when the target language term did not come into her mind at that time. Therefore, she imitated the movement of the word jump by using her hand in order to make the interlocutors understood what she meant to say.

\section{Literal translation}

To know the description of this strategy, corpus LT/S13/D5 was displayed. The utterance stated in this corpus was "I like kids bird because they are funny ..." From this data, it was noted that the Student 13 used this strategy when she could not express the ideas properly by using the target language items. The learner's utterance contained English word, but it was not properly used. The Student 13 meant to express that she liked the little birds from that movie, but she forgot the intended language item.

\section{Codeswitching}

Corpus CS/S4/D4 was the example of this strategy, "Why the tennis player why the tennis player leave his tunangannya?" From the corpus, it was clearly seen that the word "tunangannya" was definitely not an English word, however, the Student 4 decided to use it because she did not know the intended terms in the target language at that particular time.

\section{Appeal for help}

Besides the learners asked their peers and the teacher, they also utilized an electronic dictionary. The use of the electronic dictionary only took place when the learners conducted a small group discussion, particularly when their friend to whom they asked could not help them. It was proven by the result the following interview.

Because, if I do not know in English, I tend to directly ask a help to my friend or open a dictionary on my mobile phone. (Student 4); 
IJOTL TL, Vol. 4, No. 3, September 2019

p ISSN: 2502 2326; e ISSN: 2502 8278

Https://soloclcs.org; Email: ijolt1@gmail.com

Center of Language and Cultural Studies, Surakarta, Indonesia

Nugroho, Prasetio Anggit. 2019. Communication Strategies Used by EFL Learners with Different English Achievements in Oral Communication.

IJOTL TL (2019), 4(3): 138 155. DOI: 10.30957/ijotl-tl.v4i3.606.

In seeking the teacher's help, the learners tended to use a formal form, for instance, "How to say blablain English?" In contrast, they used less formal request when they sought for their friend's assistance. The example of appealing for peers' help was corpus AH/S12/D2, "If I have much free time, I will er ..oporek? spend my time in the beach". From the data above, the Student 12 applied this strategy to express his ideas during the presentation and group discussion when he really did not know how to express certain items or objects by using the target language. Therefore, he directly asked for help to the peers or the teacher

\section{Stalling/time-gaining}

There were a variety of the fillers that employed by the learners in gaining time when speaking, for instance, er, em, a, and ya. Corpus S/S2/D5 represented one of the examples of this strategy, "I thought it will willer.. told us about er.. Jakarta city, but definitely not" The students frequently used the fillers as their effort to gain more time to think about what the next statements that they would to talk or how to say some language items in the target language. Besides, they used this strategy in order to help them when they forgot and tried to recall what they want to express.

\section{Self-repair}

According to Dörnyei\& Scott (1997), self-repair strategy is making a selfinitiated correction in one's speech. In this research, self-repair strategy happened when the speakers revised their own inappropriate language items, the language structures, and pronunciation that they already produced. The examples of this strategy were presented in the following corpus:

1. SRR/S17/D2

2. SRR/S14/D5

and the light ..."

: "I will go to recreational places if I was if I were bored".

: "Because in my opinion is because the /ðə//ð $\mathbf{i} /$ effect

As shown in the data 1 , the Student 17 also revised his utterance when he produced the language with an incorrect grammar. Based on the data 2, the speaker also revised her pronunciation when she realized that the pronunciation of an article "the" was incorrect

\section{Other correction}

Other-correction strategy is the use of audiences' prompt feedback by the speakers to make their planned meaning is understandable and acceptable (Rustantya, 2016). The implementation of this strategy could be seen from the corpus ORR/S14/D1. The Student 14 used this strategy in the following situation:

\footnotetext{
Student 14 : So, conditional tenses type two is

Teacher : Conditional tenses or sentence?

Student 14 : Yes sir, conditional sentence type two is when you want to tell that ...
} 
IJOTL TL, Vol. 4, No. 3, September 2019

p ISSN: 2502 2326; e ISSN: 2502 8278

Https://soloclcs.org; Email: ijolt1@gmail.com

Center of Language and Cultural Studies, Surakarta, Indonesia

Nugroho, Prasetio Anggit. 2019. Communication Strategies Used by EFL Learners with Different English Achievements in Oral Communication.

IJOTL TL (2019), 4(3): 138 155. DOI: 10.30957/ijotl-tl.v4i3.606.

From the excerpt above, it could be noticed that the teacher gave correction directly to the student's utterances in order to avoid misunderstanding the presenter's ideas to the other students. Then, the Student 14 used the teacher's correction to proceed his utterance at that particular moment.

\section{Self-repetition}

Self-repetition strategy is repeating a lexical item or a phrase immediately after they were said (Tarone\& Yule, 1987). In the repetition, the speakers repeated a part or the whole of the utterance. This strategy had similar function with the use of fillers strategy in which the speakers repeated a word or phrase in order to fill pauses during the conversation. Corpus SRT/S14/D2 represented one of the examples of this strategy, "If I were a superhero, I would like to be a batman because because batman is rich". From the data, it could be noticed that the speaker repeated the word "because" as an effort to gain more time to think what to say next.

\section{Other-repetition}

Other-repetition strategy is the speaker's effort to repeat what the interlocutor said to gain more time (Tarone\& Yule, 1987). The example of this strategy was presented in corpus ORT/S3/D3, "what is the subject, em I will teach ..." This corpus could be understood through following excerpt:

Student 4 : What is the subject that you are going to teach?

Student 3 : What is the subject, em I will teach international relationship subject because em.. I graduated from international relationship program.

From the data above, it could be noticed that the Student 3 repeated some of the interlocutor's language items before proceeding her utterances to answer the question. This strategy was employed by the students in a specific situation which was asking and answer the question moment. Thus, the students employed this strategy to gain more time or to think about the answer to the question.

With respect to the first research question, the present research findings reveal that there are 14 types of communication strategies used by the learners. This is supported by Popescu \& Cohen-Vida (2014) that the learners used a great number of communication strategies in their communication to overcome the target language deficiencies. Sukirlan (2014a) confirmed that communication strategies used by the learners does not indicate that they are failed in the communication. On the contrary, it shows that the learners have problems in expressing their intended meaning and they need to solve the problems. However, this finding can indicate that those strategies are effective for the learners in overcoming their deficiencies about the vocabulary and the grammar knowledge.

The use of communication strategies is intended to solve the communication problems. According to Zulkurnain\& Kaur (2014), ommunication strategies are applied becausethe learners lack the target language knowledge, suchas lexical items or 
IJOTL TL, Vol. 4, No. 3, September 2019

p ISSN: 2502 2326; e ISSN: 2502 8278

Https://soloclcs.org; Email: ijolt1@gmail.com Center of Language and Cultural Studies, Surakarta, Indonesia

Nugroho, Prasetio Anggit. 2019. Communication Strategies Used by EFL Learners with Different English Achievements in Oral Communication.

IJOTL TL (2019), 4(3): 138 155. DOI: 10.30957/ijotl-tl.v4i3.606.

grammatical structures. It means that this lack of linguistic knowledge often leads toother difficulties, such as the uncertainty of using suitable vocabulary according to context andtime constraints in processing information that is going to be said or being unclear about theinterlocutores speech production. These problems are encountered by the language learners in this study. Therefore, whenever they meet difficulties in expressing their ideas, they employ communication strategies.

In accordance with the kinds of communication strategies used by the learners in this research, this study implies that the ability to overcome language deficiencies in language learning is seen as a prominent element in the process of developing the learners' speaking skill. It is in line with Syamsudin (2017) who stated that communication strategies play a constructive role in teaching and learning English as a foreign language, especially in developing the learners' speaking skill. However, some previous studies (Kongsom, 2016; Mirsane\&Khabiri, 2016) confirmed that communication strategies help the development of the learners' speaking skill. In other words, communication strategies have influence in the learners' language learning. Therefore, the language learners should take those strategies as a positive effort to overcome their target language difficulties when communicating.

In relation to the second research problem, the findings reveal that the different levels of English achievement affect the frequency of communication strategies used. From the research findings, the learners with low English achievement use communication strategies more frequently than the learners with high achievement. The findings of this research strengthen Poulise's (1993) belief that the employment of communication strategies by the language learners is correlated with the language proficiency. Communication strategy is the speaker's attempt to deal with the communication problems which is caused by the language difficulties. The students with low and high achievement might have different difficulties. Therefore, the use of communication strategies is various according to the levels of proficiency.

The findings of this research contradict with several previous studies (Uztosun\&Erten, 2014; Shokrolahi\& Ahmadi, 2016) which revealed that the use of communication strategies is not related with the learner's proficiency levels. They found that whether the occurrence of communication strategies used by the low proficient students was higher than high proficient students, but there was no significant difference statistically. Additionally, Sener\&Balkir (2013) also disagree to this research that the students with high achievement used communication strategies more frequently than the low achievement students. They found that the high achievers produce more language and they conveyed their ideas in more detail; therefore, they more frequently use the strategy in the communication.

However, research findings of this research show that the students' achievement has an effect on the use of communication strategies. It is supported by several previous studies (Ting et al., 2017; Yaman\&Ozcan, 2015) that the learner's language proficiency levels are correlated with the occurrence of communication strategies. The students with low achievement employ communication strategies more frequently than those who have high achievement because they have a different level of the language difficulties. The students with low achievement face more difficulties in their communication than 
IJOTL TL, Vol. 4, No. 3, September 2019

p ISSN: 2502 2326; e ISSN: 2502 8278

Https://soloclcs.org; Email: ijolt1@gmail.com

Center of Language and Cultural Studies, Surakarta, Indonesia

Nugroho, Prasetio Anggit. 2019. Communication Strategies Used by EFL Learners with Different English Achievements in Oral Communication.

IJOTL TL (2019), 4(3): 138 155. DOI: 10.30957/ijotl-tl.v4i3.606.

those with high achievement. In other words, the learners' language achievement affects the use of communication strategies in their oral communication.

The research findings show that the students with low achievement apply communication strategies more repeatedly than the students with high achievement. This result is supported by Maldonado (2016) who found that the frequency and the type of communication strategies are related with the learners' linguistic competence. Furthermore, the low achievement learners use communication strategies more frequently than the high achievement learners because they face more difficulties in the target language. The same argument is also stated by Mesgarshahr\&Abdollahzadeh (2014), and Shtavica (2015) that the low achievement learners use communication strategies more frequently because of their insufficient command of the target language resources. In addition, Tuan \& Mai (2015) explain that the lack of linguistic resources is caused by the students are less practice spoken English both inside and outside of the classroom. Therefore, the learners employ the communication strategies differently based on the problems which they have.

However, the low achievement learners use communication strategies more frequently does not mean that they are failed in communicating their ideas, but it shows that they do their positive attempts in solving the problems during communication. This research implies that in teaching and learning English, it is needed for the learners to be consciously aware of the benefits of communication strategies that can help to improve their speaking ability. It is supported by Saeidi\&Farshchi (2015) who argued that an explicit instruction on the use of communication strategies can help to improve the learners' speaking skill. In other words, the language teachers can utilize an explicit instruction on the use of communication strategies in the teaching and language learning.

\subsection{The Different Frequency of Using Communication Strategies between The Low and High Achievement Learners}

Based on the result of the data analysis, there was a dissimilarity in using communication strategies between the learners with low and high achievement. The following table was presented in order to know the different frequency of communication strategies which were employed by the learners with low and high English achievement in their oral communication. (See Table 2).

Table 2 The distribution of communication strategies by different English achievement

\begin{tabular}{llccc}
\hline \multirow{2}{*}{ No $\quad$ Types of Communication Strategy } & \multicolumn{2}{c}{ Low Achievement } & \multicolumn{2}{c}{ High Achievement } \\
\cline { 3 - 5 } & Frequency & $\mathbf{\%}$ & Frequency & $\%$ \\
\hline Avoidance or Reduction Strategies & 2 & $2.98 \%$ & 0 & $0 \%$ \\
1. Topic Avoidance & 3 & $4.48 \%$ & 1 & $1.61 \%$ \\
2. Message Abandonment & & & & \\
Achievement or Compensatory Strategies & 2 & $2.98 \%$ & 3 & $4.84 \%$ \\
3. Circumlocution & 1 & $1.49 \%$ & 3 & $4.84 \%$ \\
4. Approximation & 2 & $2.98 \%$ & 2 & $3.23 \%$ \\
5. Use of all-purpose words & 2 & $2.98 \%$ & 0 & $0 \%$ \\
6. Use of non-linguistic means & & &
\end{tabular}


IJOTL TL, Vol. 4, No. 3, September 2019

p ISSN: 2502 2326; e ISSN: 2502 8278

Https://soloclcs.org; Email: ijolt1@gmail.com

Center of Language and Cultural Studies, Surakarta, Indonesia

Nugroho, Prasetio Anggit. 2019. Communication Strategies Used by EFL Learners with Different English Achievements in Oral Communication.

IJOTL TL (2019), 4(3): 138 155. DOI: 10.30957/ijotl-tl.v4i3.606.

\begin{tabular}{lcccc} 
7. Literal translation & 2 & $2.98 \%$ & 0 & $0 \%$ \\
8. Code switching & 6 & $8.95 \%$ & 2 & $3.23 \%$ \\
9. Appeal for help & 3 & $4.48 \%$ & 6 & $9.68 \%$ \\
Stalling or Time-gaining Strategies & & & & \\
10. Use of fillers/hesitations & 23 & $34.33 \%$ & 14 & $22.58 \%$ \\
Other Strategies & & & & \\
11. Self-repair & 5 & $7.46 \%$ & 16 & $25.81 \%$ \\
12. Other-correction & 1 & $1.49 \%$ & 2 & $3.23 \%$ \\
13. Self-repetition & 14 & $20.89 \%$ & 10 & $16.13 \%$ \\
14. Other-repetition & 1 & $1.49 \%$ & 3 & $4.84 \%$ \\
\hline Total Frequency & $\mathbf{6 7}$ & $\mathbf{5 1 . 9 4 \%}$ & $\mathbf{6 2}$ & $\mathbf{4 8 . 0 6 \%}$ \\
\hline
\end{tabular}

Table 2suggests that there was a difference in the frequency in using communication strategies between two groups. The learners with low achievement applied communication strategies totally of 67 occasions while the learners with high achievement employed communication strategies 62 times. Learners with low English achievement used communication strategies more frequently than students with high achievement.

In detail, learners with low English achievement used fillers more frequently than learners with high achievement. The low achievement learners used fillers 23 occasions while the learners with high achievement used fillers only 14 times. Additionally, Selfrepetition strategy was the most frequently used by the learners with low achievement which its percentage of frequency was $20.89 \%$. In contrast, the learners with high achievement inclined to use a self-repair strategy with25.81 percentage of the occurrence.

In sum, the frequency in employing communication strategies between the learners with low achievement and those who had high achievement in English was different. In oral communication, learners with low achievement employed communication strategies more frequently than learners with high achievement.

\section{CONCLUSION}

Communication strategies mean the speaker's effort to make the communication keeps going on when the speaker has problems in the target language resource. In teaching and learning English as a foreign language, communication strategies are really helpful for learners to overcome their language difficulties. Therefore, they inclined to employ communication strategies to overcome their communication difficulties. From the Dornyei's (1995) taxonomy of communication strategies, the learners use 10 from 12 types of communication strategies. Besides, they employ four other communication strategies out of Dornyei's taxonomy, namely self-repair, other correction, selfrepetition, and other repetition. Thus, in overcoming the communication problems while speaking, the learners use 14 types of communication strategies altogether.

In addition, the researcher concludes that the learners' English achievement influence the frequency of using communication strategies in the learners' communication. It can be seen that the learners with low English achievement use communication strategies more frequently than the learners with high achievement. This 
IJOTL TL, Vol. 4, No. 3, September 2019

p ISSN: 2502 2326; e ISSN: 2502 8278

Https://soloclcs.org; Email: ijolt1@gmail.com

Center of Language and Cultural Studies, Surakarta, Indonesia

Nugroho, Prasetio Anggit. 2019. Communication Strategies Used by EFL Learners with Different English Achievements in Oral Communication.

IJOTL TL (2019), 4(3): 138 155. DOI: 10.30957/ijotl-tl.v4i3.606.

research implies that communication strategies is seen as a prominent element in the process of developing the learners' speaking skill; therefore, the language learners need to be consciously aware of the benefits of communication strategies that can affect their speaking ability.

\section{SUGGESTION}

For the English language teachers, they should enrich the learners' knowledge about communication strategies because it can help the learners be able to communicate effectively. However, the teachers should select the types of communication strategies which are beneficial in order to develop the learners' speaking ability. In addition, the teachers should help the learners to practice using the selected communication strategies in their oral communication strategies.

For to the learners, communication strategies were helpful for the English language learners to compensate their difficulties in delivering the messages to the listeners. However, some types of communication strategies are suggested to be used by the learners because it is acceptable to improve English speaking skill, such as circumlocution, other correction, and self-repair. Thus, it is crucial for the learners to enrich their knowledge about communication strategies because it could be fruitful for them in developing their speaking ability.

\section{REFERENCES}

Ahmed, N., Pathan, Z. H., \& Khan, F. S. (2017). Exploring the Causes of English Language Speaking Anxiety among Postgraduate Students of University of Balochistan, Pakistan. International Journal of English Linguistics, 7(2), 99105.

Al Alawi, R. A. (2016). Communication Strategies used by Omani EFL students. Pyrex Journal of English and Literature, 2(1), 1-11.

Al Hosni, S. (2014). Speaking Difficulties Encountered by Young EFL Learners. International Journal on Studies in English Language and Literature. 2(6), 2230.

Alrabai, F. (2014). A Model of Foreign Language Anxiety in the Saudi EFL Context. English Language Teaching, 7(7), 82-102.

Avval, S. F. (2012). Communication Strategies in Translation: A Review on the Taxonomies from 1977 to 2011. Journal of Siberian Federal University, 5(6), 768-779.

Brown, H. D. (2000). Principles of Language Learning and Teaching (4th ed.). New York: Longman.

Canale, M., \& Swain, M. (1980). Theoretical Bases of Communicative Approaches to Second Language Teaching and Testing. Applied Linguistics, 1(1), 1-47.

Cravotta, J. (2007). Communicative Competence: Intercultural Understanding and International Tourism. The Asian EFL Journal Quarterly, 7, 33-39.

Dornyei, Z. (1995). On the Teachibility of Communication Strategies. TESOL QUARTERLY, 29(1), 55-85. 
IJOTL TL, Vol. 4, No. 3, September 2019

p ISSN: 2502 2326; e ISSN: 2502 8278

Https://soloclcs.org; Email: ijolt1@gmail.com

Center of Language and Cultural Studies, Surakarta, Indonesia

Nugroho, Prasetio Anggit. 2019. Communication Strategies Used by EFL Learners with Different English Achievements in Oral Communication.

IJOTL TL (2019), 4(3): 138 155. DOI: 10.30957/ijotl-tl.v4i3.606.

Ellis, R. (2008). The Study of Second Language Acquisition. New York: Oxford University Pers.

Faerch, C., \& Kasper, G. (1980). Processes and Strategies in Foreign Language Learning and Communication. Interlanguage Studies Bulletin Utrecht, 5(1), 47118.

Grzegorzewska, L. (2015). The Relationship Between Anxiety and The Use of Communication Strategies. Konin Language Studies Journal, 3(3), 295-311.

Harmer, J. (2012). Essential Teacher Knowledge: Core Concepts in English Language Teaching. England: Pearson.

Kongsom, T. (2016). The Impact of Teaching Communication Strategies on English Speaking of Engineering Undergraduates.Journal of Language Teaching and Learning in Thailand, 51, 39-69.

Malasit, Y., \&Sarobol, N. (2013, March). Communication Strategies used by Thai EFL Learners. Paper presented at the Proceedings of the $3^{\text {rd }}$ International Conference on Foreign Language Learning and Teaching, Thammasat University, Thailand. Retrieved July 26, 2017, from www.filt2013.org

Maldonado, R. M. (2016). Communication Strategies Used by Different Level L2 English Learners in Oral Interaction. RevistaSignos, 49(90), 71-93.

Mesgarshahr, A., \&Abdollahzadeh, E. (2014). The Impact of Teaching Communication Strategies on EFL Learners' Willingness to Communicate.Studies in Second Language Learning and Teaching, 4(1), 51-76.

Mirsane, M., \&Khabiri, M. (2016). The Effect of Teaching Communicative Strategy on EFL Learners' Willingness to Communicate. Theory and Practice in Language Studies, 6(2), 399.

Nurdini, R. A. (2017). Communication Strategies Used by EFL Students with High and Low Self-Esteem. Journal of ELT Research, 2(1), 9-14.

Ounis, T. (2016). Exploring the Use of Oral Communication Strategies by High and Low Proficiency Learners of English: Tunisian EFL students as a case study. International Journal of Humanities and Cultural Studies (IJHCS), 3(1), 10771098.

Popescu, A. V., \& Cohen-Vida, M. I. (2014). Communication Strategies for Developing the Learner's Autonomy. Procedia-Social and Behavioral Sciences, 116, 34893493.

Poulisse, N. (1993). A Theoretical Account of Lexical Communication Strategies. In R. Screuder\& B. Weltens (Eds.), The Bilingual Lexicon (pp. 307). Amsterdam: John Benjamins.

Rustantya, A. I. (2016). Communication Strategies Employed by The Students of Accountancy Department in English for Specific Purposes (ESP) Class in STIESIA Surabaya. Thesis unpublished Universitas Negeri Malang.

Saeidi, M., \&Farshchi, E. E. (2015). The Effect of Communication Strategy Teaching on EFL Learners' Oral Production in Content-based Courses. Theory and Practice in Language Studies, 5(1), 71-78. 
IJOTL TL, Vol. 4, No. 3, September 2019

p ISSN: 2502 2326; e ISSN: 2502 8278

Https://soloclcs.org; Email: ijolt1@gmail.com

Center of Language and Cultural Studies, Surakarta, Indonesia

Nugroho, Prasetio Anggit. 2019. Communication Strategies Used by EFL Learners with Different English Achievements in Oral Communication.

IJOTL TL (2019), 4(3): 138 155. DOI: 10.30957/ijotl-tl.v4i3.606.

Sari, F. R. (2014). Communication Strategies Employed in Collaborative Reading and Speaking Activities Utilizing Movie Synopses. Thesis unpublished Universitas Negeri Malang.

Sener, S., \& Balkır, N. B. (2013). The relationship between the use of communication strategies and oral performance of ELT students: Çanakkale Onsekiz Mart University Case. ELT Research Journal, 2(2), 62-69.

Shokrolahi, M., \& Ahmadi, A. (2016). Oral Communication Strategies Used by Iranian EFL Learners: Focus on Language Proficiency and Cultural Background. International Journal of Foreign Language Teaching and Research, 4(16), 113134.

Shtavica, E. (2015). The Effects of Proficiency Level on the Communication Strategiesg among Kosovan and Bosnians Students at Sakarya University. The Online Journal of Quality in Higher Education 2(2), 97-105.

Sukirlan, M. (2013a). Taking a Closer Look at Communication Strategy and its Pedagogical Implication in EFL Class. International Conference on Education and Language, (2)1, 407-415.

Syamsudin, S. (2017). Communication Strategies in Speaking Skill of EFL Learners. English and Literature Journal, 2(01), 126-138.

Tarone, E. (1977). Conscious Communication Strategies in Interlanguage: A Progress Report. TESOL, 77, 194-203.

Tarone, E. (1977). Conscious Communication Strategies in Interlanguage: A Progress Report. TESOL, 77, 194-203.

Ting, S. H., Megawati, S., \& Lee, P. (2017). Communication Strategy Use and Proficiency Level of ESL Learners. Journal of Asia TEFL, 14(1), 162-170.

Tuan, N. H., \& Mai, T. N. (2015). Factors Affecting Students' Speaking Performance at Le Thanh Hien High School. Asian Journal of Educational Research, 3(2), 8-23.

Uztosun, M. S., \&Erten, İ. H. (2014). The Impact of English Proficiency on the Use of Communication Strategies: An Interaction-based Study in Turkish EFL Context. Journal of Language and Linguistic Studies, 10(2), pp-169.

Wicaksono, A. (2014). Are Communication Strategies Frequently Used in Speaking Class? English Teaching Journal: A Journal of English Literature, Language and Education, 2(2), 1-8.

Yaman, S., \&Özcan, M. (2015). Oral Communication Strategies Used by Turkish Students Learning English as a Foreign Language. Issues in Teaching, Learning and Testing Speaking in a Second Language (pp. 143-158).

Zulkurnain, N., \& Kaur, S. (2014). Oral English communication difficulties and coping strategies of Diploma of Hotel Management students at UiTM. 3L: Language, Linguistics, Literature, 20(3), 93-112. 